\title{
Cognitive and Communicative Pragmatic Parameters of Intertextuality in Mass Media
}

\section{Когнітивні та комунікативно-прагматичні параметри інтертекстуальності в мас-медіа}

\author{
Volodymyr Kalenych \\ Ph.D. in Philology, \\ Associate Professor
Vinnytsia Mykhailo Kotsiubynskyi
State Pedagogical University
$\checkmark$ 32, Ostrozkyi Str., Vinnytsia,
Ukraine, 21100

\author{
Володимир Каленич \\ кандидат філологічних наук, \\ доцент
}

\author{
E-mail: kalenychv@gmail.com \\ https://orcid.org/0000-0003-1768-961X
}
Вінницький державний педагогічний університет імені Михайла
Кочуюбинського
вул. Острозького, 32, Вінниця,
Україна, 21100

Original manuscript received April 20, 2019

Revised manuscript accepted February 05, 2020

\begin{abstract}
Objective. The main objective of this research is to analyse the cognitive and communicative-pragmatic parameters of intertextuality in modern mediatexts. The article deals with the peculiarities of intertextuality expression in mass media as well as identifies the main varieties of intertexts and considers their role in newspaper articles of the information-analytical weekly "Dzerkalo tyzhnya».

Research methods. Discourse analysis technique helped to identify textual and extratextual characteristics of media content. At various stages of the study, a functional analysis method is used to determine intertextuality as a means of receiving text-formation. Communicative-pragmatic analysis allowed us to find out the conditions of formation of intertextuality and generation of new meanings in intertextual crossings, which is oriented on the cognitive-speech interaction of the participants of communication (author-reader). The psycholinguistic method has
\end{abstract}


become the main scientific way of studying the processes of origin and perception of intertextuality in mediatexts. The common scientific methods of analysis and synthesis, induction and deduction, systematization, special scientific techniques of linguistic text analysis have also been used.

Results. The mediatext is a dynamic linguistic phenomenon, which responds promptly and responsibly to social-political, social-cultural and linguistic changes, reflecting the present realities in various ways. In the process of text-forming journalists try to expand the arsenal of professional means with a variety and original innovations, one of them is intertextuality.

The main intertextuality means in mediatexts are quotations, allusions and reminiscences, which are good migration ways of familiar stories, events, people, expressions in the context of mass media. These elements are integrated into the new text, cause new emotions and associations, which revive cognitive interest to the material.

Conclusions. Intertextuality is defined as a cognitive and communicative-pragmatic category, which realizes in modern mediatexts, activates cognitive and thoughtful activity of the author-journalist and the reader, stimulates intellectual searches of both communicants in the broad social-cultural space of many generations of humanity. The psycholinguistic mechanisms of the intertexts use in mass media are related to the actualization of certain images in the journalist's mind and their verbal presentation with well-known expressions, symbols, stories.

Key words: mediatext, intertextuality, quotation, allusion, reminiscence.

\section{Вступ}

Різноаспектні проблеми наукової парадигми тексту, його типологія і категорії, методики аналізу приваблюють особливий інтерес дослідників суміжних лінгвістичних галузей (лінгвістика тексту, лінгвосеміотика, психолінгвістика, етнолінгвістика, когнітивна й комунікативна лінгвістика, лінгвопрагматика, герменевтика й ін.).

О. Селіванова слушно зауважує:

«Сучасний парадигмальний простір лінгвістики представлений співіснуванням двох домінантних парадигм: прагматичної та когнітивної, адже сьогодні увага дослідників насамперед зосереджена на мові як знарядді комунікації та впливу, з одного боку, і когніції та концептуалізації, з іншого. До того ж процеси функиіонування мови в комунікації опосередковані когнітивними операчіями свідомості, що створює підгрунтя для дослідження їх у взаємодї̈» (Селіванова, 2008: 18). 
Теорія мовленнєвої діяльності, заснована О. Леонтьєвим, стала підгрунтям сучасної психолінгвістики, до актуальних проблем якої належить породження, сприйняття й розуміння мовлення та тексту (Леонтьев, 2005; Калмикова, 2008; Холод, 2009; Селіванова, 2008). Л. Калмикова підкреслює:

«Джерело всіх видів мовленнєвої діяльності - комунікативнопізнавальна потреба, яка реалізується в предметові мовленнсвої діяльності - думиі - $i$ стає внутрішнім комунікативно-пізнавальним мотивом цих видів діяльності» (Калмикова, 2015: 65).

Взаємозв'язок мовлення і мислення опосередкований мовою, яка вербалізує думку, а з іншого боку стимулює до мислетворчості й комунікації.

Медіадискурс є унікальним динамічним мовним явищем, яке оперативно й чутливо реагує на суспільно-політичні, соціокультурні й мовні зміни, різнобічно відображаючи реалії сьогодення. Він не лише інформує громадськість, а й впливає на свідомість, мислення, емоції, комунікативно-пізнавальну активність читача (слухача, глядача). Тому у процесі текстотворення мас-медійники намагаються розширювати арсенал професійних засобів різноманітними оригінальними нововведеннями, яскравим прикладом яких $\epsilon$ інтертекстуальність.

Mema cmammi - 3'ясувати когнітивні та комунікативнопрагматичні параметри інтертекстуальності в сучасних медіатекстах. Для реалізації мети поставлено такі завдання: 1) проаналізувати особливості вираження інтертекстуальності в мас-медіа; 2) схарактеризувати основні різновиди інтертекстів; 3) визначити когнітивність і комунікативний прагматизм інтертекстуальних засобів та їхню роль у медіатекстах. Матеріалом дослідження слугували публікації, представлені на сторінках інформаційноаналітичного тижневика «Дзеркало тижня» (за 2018 р.).

\section{Методи та методики дослідження}

У праці основним методом дослідження є описовий метод, що передбачає спостереження, класифікацію, узагальнення та інтерпретацію інтертекстуальних засобів у мас-медіа. 
Когнітивні та комунікативно-прагматичні параметри...

Методика дискурс-аналізу сприяла виявленню текстуальних й екстратекстуальних характеристик медіаконтенту. На різних етапах дослідження послуговувалися методом функціонального аналізу для визначення інтертекстуальності як прийому текстотворення. Комунікативно-прагматичний аналіз дозволив з'ясувати умови формування інтертекстуальності та генерування нових значень у міжтекстуальних перегуках, що орієнтовано на пізнавальномовленнєву взаємодію учасників комунікації (автор-читач). Для досягнення зазначеної мети використано також загальнонаукові методи аналізу і синтезу, індукції та дедукції, систематизації, спеціальні наукові прийоми лінгвістичного аналізу тексту.

Послуговуючись методичними рекомендаціями О. Холода, залучали психолінгвістичний метод як

«основний науковий спосіб вивчення процесів впливу, породження та сприйняття мовлення за допомогою матеріалістичної кониепиії, щзо передбачає об'єктивний взаємозв'язок психічних явищ та законів формування $i$ функиіонування мовленнсвих одиниць» (Холод, 2011: 104).

Використання контекстуально-інтерпретаційного методу орієнтоване на встановлення статусу тексту відносно інших текстів, його значимості в соціокультурному контексті, а також на реконструкцію авторського (комунікативного) задуму, мотивів і цілей, загального змісту, рецептивної спрямованості тексту тощо (Селіванова, 2008)

\section{Результати та дискусії}

Текст та його елементи сприймаються не лише як лінгвістичне явище, а й як психологічне. У психологічному і психолінгвістичному ракурсі фокусують науковці дослідницькі інтереси на мові сучасних ЗМI та медіатекстах зокрема, особливостях їхнього створення та сприймання (Холод, 2011; Мачикова, 2015; Павленко, 2015; Сизонов, 2017; Яцимірська \& Драган, 2007; Giles, 2003; Wojtaszek, 2010).

О. Холод, аналізуючи психолінгвістичні чинники мас-медійних текстів, стверджує:

«Оскільки мову журналістів розглядаємо як інструмент мас-медіа в системі психолінгвістики й теорії комунікації під 
час висвітлення діяльності суб' єктів та об'єктів громадянського суспільства, то ми зобов'язані розглянути питання про зв'язок мови журналістів із таким не мени важливим інструментом 3МI, як текст. Бо саме за допомогою основного інструменту тексту - працівники мас-медіа експлікують взаємозв'язок із громадянським суспільством» (Холод, 2011: 242).

У такій діаді «мас-медіа - громадянське суспільство» медіатекст через лінгвістичні та психологічні складники реалізує свій комунікативно-прагматичний i когнітивний потенціал - забезпечує соціум масовою інформацією, сприяє формуванню громадської думки й ціннісних орієнтацій.

Медіадискурс привертає увагу науковців своєю динамічністю й багатовимірністю, оскільки не тільки віддзеркалює розвиток суспільства, а й динаміку мовної презентації дійсності. Комунікативна взаємодія журналіст-читач опосередкована текстом як психолінгвістичним інструментом. Медіатекст може акумулювати в собі інформативність, аналітичність та образність мовленнєвої діяльності автора-журналіста, яка не лише одновекторно зорієнтована на читача, а й вимагає його взаємозворотної реакції і мисленнєвої діяльності, що посилює психологізм журналістської творчості.

Англійський мовознавець Алан Белл у праці «Approaches to Media Discourse» зазначає, що визначення медіатексту виходить за рамки традиційного погляду на текст як на послідовність слів. Воно є значно ширшим і включає голосові та звукові параметри, візуальні образи, тобто медіатексти втілюють технології, які використовуються для їх створення та поширення (Bell, 1996: 35).

Попри різноаспектну досліджуваність публіцистичних текстів, його категорій, типів, стилістики, актуальним на сучасному етапі розвитку медіалінгвістики, журналістики $є$ вивчення міжтекстових зв'язків у медіадискурсі. Останнім часом все активніше дослідники концентрують увагу на питаннях інтертекстуальності у мас-медіа і в публіцистиці загалом (Головко, 2012; Зелянко, 2012; Галич, 2015; Meinhof \& Smith, 2000; Shumin \& Puling, 2009; Ofori, 2016; Ott \& Walter, 2000; Tyner, 2009; Qin, 2018).

У монографії «Інтертекст в мас-медійному дискурсі» Б. Головко констатує, що

«інновачійність інтертексту розкривається через принциии, методи i форми втілення в практику журналізму домінантної 
Когнітивні та комунікативно-прагматичні параметри...

ролі дискурсивних прочесів, щзо сприяють організації мислетворчості, мовотворчості й систематизації базових міжтекстових відношень, використовуваних журналістом у ролі універсального інструментарію якісних текстів» (Головко, 2012: 3).

Доносячи свої думки про суспільно-політичні, економічні або культурні реалії до аудиторії, журналіст у медіатексті відображає частину свого світогляду, послуговується різноманітними комунікативно-прагматичними прийомами.

Аналізуючи семіотику інтертекстуальності публіцистичного тексту, В. Галич зауважує:

«Уведення інтертекстуальності в параметри соціального часу $i$ простору розкриває шляхи конщептуалізації дійсності та вектори комунікативних і культурних стратегій доби» (Галич, 2015: 4).

Звернення до «чужих текстів», на думку дослідниці, пов'язане перш за все 3 прагненням самого автора поглибити свою думку й активізувати експліцитний та імпліцитний зміст твору.

Різноаспектність і поліфункціональність інтертекстуальності в українському медіадискурсі засвідчують дослідження цієї категорії тексту: інтертекстуальна парадигма журналістського тексту (Зражевська, 2007), інтертекстуальність як жанротвірний чинник у сучасній українській есеїстиці (Іванюха \& Полякова, 2015), інтертекстуальність і прецедентність в україномовних 3МІ початку XXI ст. (Ільченко, 2013), інтертекстуальність у дискурсі сучасної української преси (Рябініна, 2008) тощо.

Українська дослідниця інтертексту Н. Зражевська зазначає, що існують текстові і мовні прояви інтертектуальності: текстові передбачають наявність цитат, ремінісценцій, алюзій (експліцитний фрагмент у тексті та імпліцитно пов'язані з ним асоціації), мовні стосуються присутності в тексті певного функціонального стилю, що веде переважно до забарвлення змісту, композиції, жанру публіцистичного тексту і сприяє виявленню етичних, моральних, професійних та інших аспектів повідомлення (Зражевська, 2007).

Механізм текстотворення, способи введення в текст тих чи інших когніцій тісно пов'язані із психічною діяльністю і мають когнітивну зумовленість: розуміння інтертексту, як і тексту загалом, об'єктивує когнітивний фон повідомлюваного і ментальною діяльністю комунікантів (при творенні тексту і його сприйнятті). 
Розглядаючи поняття інтертекстуальності крізь призму теорії мовленнєвої дії О. Леонтьєва, зауважимо, що психолінгвістичні аспекти мовленнєвого впливу інтертекстів пов'язані з активізацією психічних процесів (мислення, мовлення, пам'ять, сприйняття, увага, уява, емоції тощо), що відображає смисловий взаємозв'язок i взаємозумовленість комунікатора i реципієнта та семіотичну опосередкованість процесів мовленнєвого спілкування (йдеться саме про психолінгвістичні процеси сприйняття і породження текстів журналістів). Л. Калмикова констатує:

«У якості продукту рецептивних (ідеальних) видів мовленнєвої діяльності (слухання, читання) виступають умовисновки, які робить людина в процесі рецепиії. У висловлюваннях, текстах об'єктивується вся сукупність психологічних умов діяльності та індивідуально-психологічні особливості іï суб'єкта» (Калмикова, 2015: 65).

Мовленнєво-мисленнєва діяльність активізує комунікативну й пізнавальну сферу як вищі духовні потреби людини. Так, у процесі сприймання медіатексту свідомість реципієнта акумулює основні думки зі свідомості й світогляду автора, які читач має осмислити й дійти до певних умовисновків.

Інтертекст трактуємо як когнітивно-комунікативну одиницю, що $\epsilon$ текстотвірним елементом та реалізує ідейно-тематичний задум автора. Інтертекстуальність як ментальне явище пов'язане зі збереженою інформацією, яку актуалізує медіатекст, з іншого боку, невідоме в ньому стимулює до пошуку і продовження пізнавальномовленнєвої діяльності із залученням інших ресурсів (літератури, культури, історії, інтернету, досвіду знайомих тощо).

Незвичайні асоціативні висловлювання, прямі та приховані цитати, ремінісценції та алюзії, глибокий підтекст та інші засоби дозволяють авторові посилити ефект журналістського твору, повніше реалізувати власну творчу інтенцію (Іванюха \& Полякова, 2015). «Закодована» у такий спосіб інформація розрахована на спорідненість психокогнітивних можливостей i комунікативного прагматизму автора та реципієнтів.

Одним зі способів організації тексту й найбільш продуктивних інтертекстуальних прийомів у медіатекстах є цитація (використання в тексті фрагменту іншого тексту, вислову). За Н. Фатєєвою, 
цитата - відтворення двох чи більше компонентів тексту-донора 3 власною предикацією. Цитата активно націлена на радість упізнавання, але ця спрямованість може бути як експліцитною, так й імпліцитною. Тому цитати можна класифікувати за ступенем їхньої атрибутивності щодо вихідного тексту, а саме за тим, чи виявляється інтертекстуальний зв'язок з'ясованим фактором авторської побудови та читацького сприйняття тексту чи ні (Фатеева, 2000).

Цитати, фрагменти цитат або навіть окремі слова чи словосполучення, колись влучно сказані, написані, допомагають зміцнити текстовий матеріал у єдиний твір, разом із тим спонукають читача спрямувати пізнавально-мисленнєву діяльність у сферу інтертексту і внести в текст-реципієнт додатковий смисл. У публікаціях газети «Дзеркало тижня» трапляються прямі (або експліцитні, марковані, атрибутивні) цитати, які містять пряму вказівку на автора чи претекст:

«Цей світ має лише естетичне виправдання», - казав Альбер Камю (№ 22. - С. 12); Як зазначає Р. Барт у свойй праичі "До психосоиіології сучасного споживання їжі», «Їжа - ие система комунікації, де одиницею є не самі продукти, а сенси й властивості, щео надаються продуктам» (№ 50. - С. 11);

а також непрямі (або імпліцитні, немарковані, неатрибутивні) цитати - не містять ніяких маркувань:

Подивімося на ситуачію в ОРДЛО і Криму: «На всіх язиках все мовчить, бо благоденствує» (№ 24-25. - С. 2) - вислів 3 поеми «Кавказ» Т. Шевченка.

У медіа використовують також фрагменти відомих цитат, які в новому контексті набувають авторських модифікацій та інтерпретацій:

Громадяни иієї Скандинавської країни були ледь не шоковані «і ланами широкополими, і Дніпром, і кручами» (№ 44. - С. 8) - 3 поезії Т. Шевченка «Заповіт»; Однак ие не означає, що роботу в иьому напрямі слід припинити. Навпаки, потрібно «лупати июю скалу» і надалі (№ 26. - С. 7) - 3 поезії І. Франка «Каменярі».

Такі інтертекстуальні засоби функціонують як прийом мовної гри з елементами аплікації:

3 легкої руки Кобзаря ми чекали «Вашингтона з новим $i$ праведним законом». Тепер чекаємо умовного «Макрона» 3 
чим-небудь «новим і праведним» за пазухою (№ 31. - С. 3) - 3 поезії Т. Шевченка «Юродивий».

Розмірковуючи над проблемами сьогодення, журналісти вдаються до перефразування афористичних висловлювань, що посилює імпресивність викладу думок у тексті:

Перефразовуючи відомий вислів, можна констатувати: «Скажи мені, хто тебе підтримує, і я скажу, хто ти» (№ 29. - С. 5); Перефразовуючи Черчилля, можна сказати, щзо сучасний Захід це не найліпша конфігурачія, частиною якої хотілося б стати, але крашуої людство наразі не вигадало (№ 28. - С. 4).

Цитати як інтертекстуальні засоби реалізують текстотвірний потенціал. Наприклад, цитату автори використовують у ліді статті, фокусуючи увагу на висвітлюваній проблемі:

«Шукай, кому вигідно», - вчив народний трибун Риму Луціий Кассій Лонгін Равілла. Застосувати ие правило в історії 3 нападом на херсонську активістку Катерину Гандзюк непросто (№ 42-43. - C. 1).

Крилатими висловами послуговуються у кінці публікації як резюме до викладеного:

Удосконалення системи управління наукою зміцнить надію на те, щзо майбутнє в Украӥни є. Але при цзьому слід пам'ятати мораль відомої байки: «Беда, коль пироги начнет печи сапожник, а сапоги тачать пирожник» (№ 29. - С. 12).

Така композиційна декоративність у медіадискурсі посилює його комунікативно-прагматичний потенціал, надаючи довершеності опублікованому матеріалу.

Своєрідним автономним паратекстуальним елементом в архітектоніці медіатекстів є епіграф.

«Ужитий після заголовка перед текстом, він у композиційній структурі виконує роль експозищї й сприймається як пояснення, ...як натяк на головний конфлікт твору» (Галич, 2015: 48).

Наприклад, у газеті «Дзеркало тижня» епіграфами до публікацій є такі вислови відомих діячів культури, політики, прислів'я або приказки:

Всяке мистецтво має на меті привести до порядку певну розхристану у житті людину. Лесь Курбас (№ 27. - С. 12. - 
Мистецтво грошей як пріоритет довіри); Повірте, що зможете, i півшляху вже пройдено. Теодор Рузвельт (№ 50. - С. 13. У грі чи поза грою?); Домовилася кішка з мишею, $i$ будинок зруйнувався. Сирійська приказка (№ 34. - С. 1. - Ідлібський фронт Путіна-Ердогана) та ін.

Епіграф певним чином забезпечує психологічну підготовку читача до сприймання медіатексту, лаконічно і влучно передає його ідею, актуалізуючи асоціативні зв’язки чи проведення аналогій. Так, у своїй статті «Вулканічний синдром» (№ 23. - С. 1) В. Горбулін у ролі епіграфа цитує висловлювання американського письменника Френсіса Скотта Фіцджеральда: «Невміння правильно себе оцінювати - ось щзо може тобі зашкодити в майбутньому», розглядаючи в тексті проблеми весняного політичного загострення в міжнародній політиці, геополітичні питання, роль лідерів передових держав на міжнародній арені і т. д. Автор ділить статтю на частини, кожна $з$ яких також має свій епіграф:

«США вибудовування нових кордонів світосистеми» - Якщо бажаєм, щоб світ змінився, - сам стань цією зміною (Махатма Ганді); «Берлін-Париж-Москва: нова архітектура «Мюнхенської змови»?» - Європи ніколи не існувало. Європа - не сума начіональних суверенітетів ... Свропу ще треба створити (Жан Монне); «Україна: пошук себе у світі національного егоїзму» Людина повинна мріяти, щоб бачити смисл життя (Вольтер).

Скорочена цитата 3 Євангелія «..бо багато званих, та мало обраних» (Мф. 20: 16; 22:14) стала епіграфом до статті А. Шарова «Національний банк: «Хто на новенького?»» (№ 2. C. 1) про призначення нового голови Нацбанку України Я. Смолія i про тривалий процес у виборі кандидатури, фінансовоекономічні питання.

Займаючи автономну позицію, епіграф служить засобом вираження авторських інтенцій, що сприяє досягненню когнітивного балансу «автор-читач». Для формування читацької установки важливий не тільки епіграф, а й його походження: часова, просторова, соціокультурна віддаленість джерела. Найчастіше джерелом епіграфів стають різні прецеденті тексти: фольклор, релігійні твори, художні тексти, висловлювання відомих людей.

Особливий комунікативно-прагматичний потенціал мають заголовки, у яких використовуються трансформовані усталені 
вирази, вирізняючись не тільки експресією, а й своєрідним інформаційним кодом до медіатексту:

Per aspera ad astra Хмельниччини (№ 12. - С. 15); Піймати МВФ за бороду (№ 16. - С. 1); Трамп Китаю не товариш (№ 29. С. 1); Повернення блудної схеми (№ 30. - С. 9); Бійся китайців, які приносять дарунки (№ 32. - С. 8); Старий ворог кращий за нових двох? (№ 42. - С. 4).

Такі оказіональні вирази є упізнаваними, оскільки зафіксовані свідомістю автора й читача як фразеологічні одиниці, 3 іншого боку - як елементи мовної гри конотативно ілюструють переосмислення проблеми, порушеної в публікації.

Алюзї як інтертекстуальні прийоми образності й виразності створюють асоціації за рахунок натяку на досить відомі історичні чи літературні факти, події, фрази, персонажів інших текстів 3 розрахунку на ерудицію читача:

Нам подобається потрапити в історію величних перемін, нехай $i$ на «Титаніку» (№ 15. - С. 13); У середині 2016 р. я попереджав про серйозний ризик того, щзо Європа може стати певним колективним «гюлленцем» із твору Фрідріха Дюрренматта «Гостина старої дами» $i$ здати - під зовні гарним $і$ внутрішньо ціілком практичним приводом - Україну (№ 23. - С. 2); Як тільки усвідомимо, щуо ми - сім'я (причому не Кайдашева), до Кремнієвої долини буде рукою подати (№ 28. - С. 3); Он «Картковий будинок» усього через кілька років на тлі нинішнього Білого дому здається вже не спробою стягнути простирадло, а нудною псевдодокументалістикою (№ 50. - С. 1).

Моделюючи ситуації чи події через призму індивідуального світобачення і світосприйняття, автор використовує різні засоби для довершення творення образів, для інтерпретації дійсності, переконання читача - це відображає його інтелектуальний рівень та пізнавально-мисленнєві здібності. Алюзія має потужний когнітивний потенціал, оскільки викликає у свідомості читача два контексти i дві ситуації: асоціативно відсилає до прототексту, звідки взято образ, та збагачує певними конотаціями новостворений текст. Психолінгвістичний механізм творення i розуміння таких інтертекстів являє собою мнемотехніку одного 3 видів мовної гри. 
Прийом аплікації використовують журналісти в заголовкахалюзіях, які відсилають читача до заголовка відомого твору, але щодо медіатексту зазнають метаморфози:

Шагренева шкіра ринку иукру (№ 38. - С. 9); За ким пенсійний подзвін (№ 41. - С. 7); Перехресні стежжки корифеїв українського театру (№ 46. - С. 16); Дивовижний новий економічний світ (№ 49. - С. 9); Мовчання ягнят, або Правда про емоційне насильство (№ 48. - С. 13).

Інтертекстуальна прагматика властива ономастичним засобам (імена культурних і політичних діячів, літературних персонажів, бібліоніми, міфоніми й ін.):

Історія - найбільший містифікатор $i$ водночас викривач. Джкордано Бруно і Джузеппе Каліостро в одній особі (№ 12. С. 5); Навіть егоїстичний творець (а бувають інші?) завжди діалогічний, звідси й невдала спроба забути Герострата. Тобто творча особистість тим вільніма, чим ї̈ витвори соціальнімі (№ 23. - С. 10); Ну кому хочеться деталізувати, щзо саме в нього в кишківнику, якщо він, наприклад, любитель Тиціана, Боттічеллі та різних інших мікеланджело? (№ 27. - С. 12); I якщо Мадуро не полишить владу добровільно, то наступного разу все може бути по-справжньому. Тоді йому вже не уникнути долі Муаммара Каддафі, Ніколає Чаушеску або Муссоліні. (№ 29. - С. 5.).

Як приклад алюзії, вони образно й символічно передають авторську інтенцію щодо повідомлюваного, для розкодування якої необхідно знати не лише цих осіб, а й ситуації, через що вони увійшли в історію людства.

Ремінісценція як стилетворчий елемент медіатексту передбачає уведення до певного твору фрагментів, які нагадують адресатові події, факти, героїв, стилістичні прийоми, мотиви іншого тексту, що може проявлятися в подібності. Так, Ю. Туниця на початку статті «Труба раз, труба два... I балтійській екосистемі - «труба»?» (№ 26. - С. 12) вдається до літературної ремінісценції:

«Дискусії навколо будівниџтва «Північного потоку-2» нагадують трагічний сюжет оповідання Михайла Старицького «Понизив!», коли сільські хлопчі засперечалися на два відра горілки, чи Петро зіб'є кулею з голови Антона шапку, не простреливши їі». 
Розв'язка цього безглуздого дійства була трагічною, бо «понизив». Потім автор наводить свій коментар щодо порушеної в публікації проблеми:

«Щоб сьогодні не «понизити» $i$ не поцуілтти нищівним ударом в унікальну екологічну систему Балтійського моря, маємо акиентувати увагу не на економічних $i$ політичних інтересах, як изе відбувається досі («шапка» $\check{u}$ «горілка»), а на високій імовірності масштабної екологічної катастрофи в Балтійському регіоні («голова»)».

Такі позасюжетні елементи не порушують архітектоніки медіатексту, а є ліричними відступами, композиційними паралелями. Психолог К. Гольцберг у статті «Метафізика шлюбу, або 3 ким ми можемо бути щасливими» (№ 5. - С. 13) розмірковує про «філософію благополучного шлюбу», сімейні стосунки чоловіка i дружини, вибір ідеального партнера тощо. Автор вдається до ремінісценції і наводить приклад зі старого фільму «Екіпаж», коли командир корабля Тимченко звертається до молодої вродливої стюардеси, закоханої в ловеласа Скворцова, і каже, що вже багато дівчат намагалися змінити Скворцова, однак досі нікому це не вдалося, хоч би якими чудовими були ці дівчата, і що тікати треба від таких ось скворцових не озираючись, аби не зіпсувати собі життя. «Вам же теж відомі випадки, коли чоловік роками морочить голову прекрасній в усіх сенсах дівчині, а потім, розлучившись із нею, через три дні одружується 3 іншою - цілком звичайною. I вони навіть бувають щасливими». Далі психолог звертається до ремінісцентних образів «архетипічних персонажів - героїнь казок» Мальвіни, Герди, Русалоньки, які надзвичайно сильно прагнуть змін у своїх коханих, бажаючи домогтися «ідеальності» і повної відповідності партнера своїм фантазіям, а врешті-решт виходять зі стосунків розчарованими, проте вони самі з часом змінюються. Такі позалінгвальні паралелі увиразнюють розповідь, вдало ілюструють психологічні тези щодо проблеми статті.

Введення в медіатекст інтертекстуальних засобів вимагає додаткових стимулів пам'яті адресанта й адресата, з якої вилучаються певні відомості (знання). Автор апелює до підсвідомості читача, у якій зберігаються когніції, пов'язані 3 інтертекстами. У разі відсутності таких знань читач прагне заповнити невідоме шляхом 
Когнітивні та комунікативно-прагматичні параметри...

пошуку першоджерел нерозкодованих інтертекстів у літературі, культурі, історії, науці тощо.

\section{Висновки}

Ефективність інтертекстуального мислення залежить від комунікативно-когнітивної компетентності автора і читача. Використовуючи певні інтертексти, автор, з одного боку, вдається до економії мовних засобів, а 3 іншого - зважає на особливості їхнього сприйняття, розуміння й наслідки впливу на реципієнта. Комунікативно-прагматичні інтенції авторського задуму орієнтовані на те, щоб для висвітлення порушеної проблеми дібрати найвиразніші мовні засоби, які $б$ експліцитно та імпліцитно впливали на свідомість читача, його когнітивну й емоційну сфери, стимулювали мисленнєву діяльність, активізували пам'ять, компенсували ерудицію новими знаннями. Такий психолінгвістичний механізм увиразнює журналістську творчість і медіатексти зокрема.

Інформативність журналістського мовлення (у широкому розумінні поняття) корелює 3 його когнітивністю, адже читач не лише отримує інформацію про сьогодення, а й пізнає світ, відображаючи його у свідомості як взаємозв'язки 3 минулим досвідом. Інтертекстуальні засоби (цитати, алюзії, ремінісценції) створюють смислову перспективу, посилюють емоційність тексту. Потрапляючи в новий контекст, відомі образи, символи, фрази реалізують нову експресивну енергію, змінюють свою стилістику.

Отже, інтертекстуальність як когнітивна i комунікативнопрагматична категорія, реалізуючись у сучасних медіатекстах, активізує пізнавально-мисленнєву діяльність як автора-журналіста, так і читача-адресата, стимулює до інтелектуальних пошуків обох комунікантів у широкому й багатогранному соціокультурному просторі багатьох поколінь людства. Психолінгвістичні механізми використання інтертекстів у журналістських творах пов'язані 3 актуалізацією певних образів у свідомості журналіста та їх вербальною презентацією загальновідомими висловлюваннями, символами, сюжетами й ін.

Перспективним вбачаємо дослідження екстралінгвістичних та інтралінгвістичних механізмів інтертекстуальності в мові преси, 
взаємозв’язку мовлення й мислення при розкодуванні інформації інтертекстів.

\section{Література}

Галич, В.М. (2015). Семіотика інтертекстуальності публіцистичного твору: соціально-комунікативна рецепція. (Монографія). Рівне: ДЗ «Луганський національний університет імені Тараса Шевченка».

Головко, Б.Н. (2012). Интертекст в мас-медийном дискурсе. Москва: Книжный дом «Либроком».

Зелянко, С.В. (2012). Інтэртэкст у публіцыстыьчным маўленні. Мінск: БДУ.

Зражевська, H.I. (2007). Інтертекстуальна парадигма журналістського тексту. Стиль і текст, 8, 89-99.

Іванюха, Т.В., \& Полякова, Г.О. (2015). Інтертекстуальність як жанротвірний чинник у сучасній українській есеїстиці. Держава та регіони. Серія: Соціальні комунікації, 3 (23), 43-48.

Ільченко, О.А. (2013). Інтертекстуальність і прецедентність в україномовних 3МІ початку XXI ст. (на матеріалі метафоричних словосполучень). Лінгвістичні дослідження, 35, 155-160.

Калмикова, Л.О. Калмиков, Г.В., Лапшина, І.М., \& Харченко, Н.В. (2008). Психологія мовлення і психолінгвістика. Київ: Фенікс.

Калмикова, Л.О. (2015). Мовленнєва діяльність як складова предмета психолінгвістики. East European Journal of Psycholinguistics, 2 (1), 59-67.

Леонтьев, А.А. (2005). Основы психолингвистики. Москва: Смысл; Академия.

Мачикова, М. (2015). Медіа в контексті психолінгвістики та медіапсихології. East European Journal of Psycholinguistics, 2 (2), 118-126.

Павленко, В.В. (2015). Когнітивний підхід до вивчення медіадискурсу. Держава та регіони. Серія: Сочіальні комунікації, 4 (24), 48-51.

Рябініна, О.К. (2008). Інтертекстуальність у дискурсі сучасної української преси: лінгвістичний аспект. Автореф. дис. канд. філол. наук. Харків.

Селіванова, О.О. (2008). Сучасна лінгвістика : напрями та проблеми. Полтава: Довкілля-К.

Сизонов, Д.Ю. (2017). Психолінгвістичні основи медіаграмотності: до проблеми інтерпретації медіатекстів. Science and Education, 7, 82-88.

Фатеева, Н.А. (2000). Контрапункт интертекстуальности, или интертекст 6 мире текстов. Москва: Агар.

Холод, О.М. (2009). Зібрання наукових працъь: у 10 т. Т. 3: Психолінгвістика масмедіа. Кривий Ріг.

Холод, О.М. (2011). Соціальні комунікації: соичіо- $і$ психолінгвістичний аналіз. Львів: ПАІС.

Яцимірська, М., \& Драган, Н. (2007). Мідеатекст як продукт журналістської творчості (психолінгвістичний аналіз логічного сприйняття та емоцій). Вісник Львівського університету. Серія журналістика, 30, 267-276.

Bell, A. (1996). Approaches to Media Discourse. London: Blackwell Publishers.

Meinhof, U., \& Smith, J. (2000). Intertextuality and the Media. From Genre to Everyday Life. Manchester and New York: Manchester University Press.

Giles, D. (2003). Media Psychology. New York: New York University Press. https://doi.org/10.4324/9781410607263 
Shumin, Jiao, \& Puling, Lu. (2009). The Influence of Network News Intertextual Narrative on Newspaper News Narrative. Contemporary Communications, 3, 102-103.

Ofori, E.A. (2016). Intertextuality and the Representation of Insults in Pro-NPP and Pro-NDC Newspapers: A Critical Discourse Analysis. Theory and Practice in Language Studies, 6 (9), 1739-1747. https://doi.org/10.17507/tpls.0609.03

Ott, B., \& Walter, C. (2000). Intertextuality: Interpretive Practice and Textual Strategy. Critical Studies in Media Communication, 17 (4), 429-446. https://doi. org/10.1080/15295030009388412

Tyner, K. (2009). Audiences, Intertextuality, and New Media Literacy. International Journal of Learning and Media, 1 (2), 25-31. https://doi.org/10.1162/ijlm.2009.0020

Qin Xie (2018). Analysis of Intertextuality in English News Headlines. Theory and Practice in Language Studies, 8 (8), 1010-1014. https://doi.org/10.17507/ tpls.0808.13

Wojtaszek, A. (2010). Relative salience of information and associative connotations in press advertisments. Psycholinguistics: scientific and technological challenges (pp. 364-376). Porto Alegre : EDIPUCRS.

\section{References}

Halych, V.M. (2015). Semiotyka intertekstualnosti publitsystychnoho tvoru: sotsialnokomunikatyvna retseptsiya [Semiotics of intertextuality of a journalistic work: social-communicative reception]. Rivne: DZ «Luhanskyy natsionalnyy universytet imeni Tarasa Shevchenka» [in Ukrainian].

Golovko, B.N. (2012). Intertekst v mas-mediynom diskurse [Intertext in the mass media discourse]. Moscow: Knizhnyy dom «Librokom» [in Russian].

Zelianko, S.V. (2012) Intertekst u publicystychnym mawlienni [Intertekst in publicistic speech]. Minsk: BDU [in Byellorussian].

Zrazhevska, N. (2007). Intertekstualna paradyhma zhurnalistskoho tekstu [Intertextual paradigm of journalistic text]. Styl $i$ tekst - Style and Text, 8, 89-99 [in Ukrainian].

Ivanyukha, T.V., \& Polyakova, H.O. (2015) Intertekstualnist yak zhanrotvirnyy chynnyk u suchasniy ukrayinskiy eseyistytsi [Intertextuality as a genre-forming factor in a modern Ukrainian essay]. Derzhava ta rehiony. Seriya: Sotsialni komunikatsiyi - State and Regions. Series: Social Communications, 3 (23). 43 48 [in Ukrainian].

Ilchenko, O.A. (2013). Intertekstualnist i pretsedentnist $\mathrm{v}$ ukrayinomovnykh ZMI pochatku XXI st. (na mat. metaforychnykh slovospoluchen) [Intertextuality and precedentuality in Ukrainian mass media of the beginning of the XXI century (in the material metaphoric word combination)]. Linhvistychni doslidzhennya Linguistic research, 35, 155-160 [in Ukrainian].

Kalmykova, L.O., Kalmykov, G.V., Lapshyna, I.M., \& Kharchenko, N.V. (2008). Psykholohiya movlennya $i$ psykholinhvistyka [Psychology of Speech and Psycholinguistics]. Kyiv: Feniks [in Ukrainian].

Kalmykova, L.O. (2015). Movlennyeva diyalnist yak skladova predmeta psykholinhvistyky [Speech activity as a component of the psycholinguistics object]. East European Journal of Psycholinguistics, 2 (1), 59-67 [in Ukrainian].

Leontiev, A.A. (2005). Osnovy psiholingvistiki [Fundamentals of psycholinguistics]. Moscow: Smysl; Akademija [in Russian]. 
Machykova, M. (2015) Media v konteksti psykholinhvistyky ta mediapsykholohiyi [Media in the context of psycholinguistics and mediapsychology]. Eastern European Journal of Psycholinguistics, 2 (2), 118-126 [in Ukrainian].

Pavlenko, V.V. (2015). Kohnityvnyy pidkhid do vyvchennya mediadyskursu. [Cognitive approach to media discourse studying]. Derzhava ta rehiony. Seriya: Sotsialni komunikatsiyi - State and regions. Series: Social Communication, 4 (24). 48-51 [in Ukrainian].

Ryabinina, O.K. (2008). Intertekstualnist u dyskursi suchasnoyi ukrayinskoyi presy: linhvistychnyy aspekt [Intertextuality in the discourse of modern Ukrainian press: linguistic aspect]. Extended abstract of candidate's thesis. Kharkiv [in Ukrainian].

Selivanova, O.O. (2008). Suchasna linhvistyka: napryamy ta problemy [Modern Linguistics: Directions and Problems]. Poltava: Dovkillya-K [in Ukrainian].

Syzonov, D.Yu. (2017). Psykholinhvistychni osnovy mediahramotnosti: do problemy interpretatsiyi mediatekstiv [Psycholinguistic bases of media literacy: considering the issue of mediatexts interpretation]. Science and Education, 7, 82-88 [in Ukrainian].

Fateyeva, N.A. (2000). Kontrapunkt intertekstualnosti, ili intertekst v mire tekstov [Counterpoint of intertextuality, or intertext in the world of texts]. Moscow: Agar [in Russian].

Kholod, O.M. (2009). Zibrannya naukovykh prats [Collection of scientific works]. (Vol. 1-10). Kryvyi Rih [in Ukrainian].

Kholod, O.M. (2011). Sotsialni komunikatsiyi: sotsio- $i$ psykholinhvistychnyy analiz [Social communications: social and psycholinguistic analysis]. Lviv: PAIS [in Ukrainian].

Yatsymirska, M., \& Drahan, N. (2007). Mideatekst yak produkt zhurnalistskoyi tvorchosti (psykholinhvistychnyy analiz lohichnoho spryynyattya ta emotsiy) [Mediatext as a result of journalistic creativity (psycholinguistic analysis of logical perception and emotion)]. Visnyk Lvivskoho universytetu. Seriya zhurnalistyka. Visnyk of the Lviv University. Series Journalism, 30, 267-276 [in Ukrainian].

Bell, A. (1996). Approaches to Media Discourse. London: Blackwell Publishers.

Meinhof, U., \& Smith, J. (2000). Intertextuality and the Media. From Genre to Everyday Life. Manchester and New York: Manchester University Press.

Giles, D. (2003). Media Psychology. New York: New York University Press. https:// doi.org/10.4324/9781410607263

Shumin, Jiao, \& Puling, Lu. (2009). The Influence of Network News Intertextual Narrative on Newspaper News Narrative. Contemporary Communications, 3, 102-103.

Ofori, E.A. (2016). Intertextuality and the Representation of Insults in Pro-NPP and Pro-NDC Newspapers: A Critical Discourse Analysis. Theory and Practice in Language Studies, 6 (9), 1739-1747. https://doi.org/10.17507/tpls.0609.03

Ott, B., \& Walter, C. (2000). Intertextuality: Interpretive Practice and Textual Strategy. Critical Studies in Media Communication, 17 (4), 429-446. https://doi. org/10.1080/15295030009388412

Tyner, K. (2009). Audiences, Intertextuality, and New Media Literacy. International Journal of Learning and Media, 1 (2), 25-31. https://doi.org/10.1162/ijlm.2009.0020

Qin Xie (2018). Analysis of Intertextuality in English News Headlines. Theory and Practice in Language Studies, 8 (8), 1010-1014. https://doi.org/10.17507/tpls.0808.13

Wojtaszek, A. (2010). Relative salience of information and associative connotations in press advertisments. Psycholinguistics: scientific and technological challenges (pp. 364-376). Porto Alegre : EDIPUCRS. 
Когнітивні та комунікативно-прагматичні параметри...

\section{АНОТАЦІЯ}

Мета дослідження - з'ясувати когнітивні та комунікативно-прагматичні параметри інтертекстуальності в сучасних медіатекстах. у статті проаналізовано особливості вираження інтертекстуальності в мас-медіа, схарактеризувано основні різновиди інтертекстів, визначено їхню роль у газетних публікаціях інформаційно-аналітичного тижневика «Дзеркало тижня».

Методики дослідження. У праці методика дискурс-аналізу сприяла виявленню текстуальних й екстратекстуальних характеристик медіаконтенту. На різних етапах дослідження послуговувалися методом функціонального аналізу для визначення інтертекстуальності як прийому текстотворення. Комунікативно-прагматичний аналіз дозволив з'ясувати умови формування інтертекстуальності та генерування нових значень у міжтекстуальних перегуках, що орієнтовано на пізнавально-мовленнєву взаємодію учасників комунікації (автор-читач). Психолінгвістичний метод став основним науковим способом вивчення процесів породження та сприйняття інтертекстуальності в медіатекстах. Для досягнення зазначеної мети використано також загальнонаукові методи аналізу і синтезу, індукції та дедукції, систематизації, спеціальні наукові прийоми лінгвістичного аналізу тексту.

Результати. Медіатекст є динамічним мовним явищем, яке оперативно й чутливо реагує на суспільно-політичні, соціокультурні й мовні зміни, різнобічно відображаючи реалії сьогодення. У прочесі текстотворення мас-медійники намагаються розширювати арсенал професійних засобів різноманітними оригінальними нововведеннями, яскравим прикладом яких $\epsilon$ інтертекстуальність. Основними інтертекстуальними засобами в медіатекстах є цитати, алюзії та ремінісценції, які є вдалими прийомами міграції відомих сюжетів, подій, осіб, висловів у контексті мас-медіа. Такі елементи, інтегровані в новий текст, викликають нові емоції та асоціації, які у свою чергу пожвавлюють пізнавальний інтерес до матеріалу.

Висновки. Визначено інтертекстуальність як когнітивну і комунікативнопрагматичну категорію, яка, реалізуючись у сучасних медіатекстах, активізує пізнавально-мисленнєву діяльність як автора-журналіста, так і читачаадресата, стимулює до інтелектуальних пошуків обох комунікантів у широкому й багатогранному соціокультурному просторі багатьох поколінь людства. Психолінгвістичні механізми використання інтертекстів у мас-медіа пов'язані з актуалізацією певних образів у свідомості журналіста та їх вербальною презентацією загальновідомими висловлюваннями, символами, сюжетами.

Ключові слова: медіатекст, інтертекстуальність, цитата, алюзія, ремінісценція. 
Cognitive and Communicative Pragmatic Parameters of Intertextuality...

Каленич Владимир. Когнитивные и коммуникативно-прагматические параметры интертекстуальности в масс-медиа

\begin{abstract}
АННОТАЦИЯ
Цель исследования - рассмотреть когнитивные и коммуникативнопрагматические параметры интертекстуальности в современных медиатекстах. В статье проанализированы особенности выражения интертекстуальности в масс-медиа, охарактеризованы основные разновидности интертекстов, определена их роль в газетных публикациях информационно-аналитического еженедельника "Зеркало недели».
\end{abstract}

Методики исследования. В работе методика дискурс-анализа способствовала выявлению текстовых и экстратекстуальных характеристик медиаконтента. На разных этапах исследования использован метод функционального анализа для определения интертекстуальности как приема текстообразования. Коммуникативно-прагматический анализ позволил выяснить условия формирования интертекстуальности и генерирования новых значений в межтекстовых связях, что ориентировано на познавательноречевое взаимодействие участников коммуникации (автор-читатель). Психолингвистический метод стал основным научным методом исследования процессов порождения и восприятия интертекстуальности в медиатекстах. Для достижения указанной цели использовано также общенаучные методы анализа и синтеза, индукции и дедукции, систематизации, специальные научные приемы лингвистического анализа текста.

Результаты. Медиатекст есть динамичным языковым явлением, которое оперативно и чутко реагирует на общественно-политические, социокультурные и языковые изменения, разносторонне отражая реалии современности. В процессе текстообразования журналисты пытаются расширять арсенал профессиональных средств различными оригинальными нововведениями, ярким примером которых является интертекстуальность. Основными интертекстуальными средствами в медиатекстах есть цитаты, аллюзии и реминисценции, которые являются удачными приемами миграции известных сюжетов, событий, лии, выражений в контексте масс-медиа. Такие элементы, интегрированные в новый текст, вызывают новые эмоции и ассоциации, которые в свою очередь оживляют познавательный интерес к материалу.

Выводы. Интертекстуальность определена как когнитивная и коммуникативнопрагматическая категория, которая, реализуясь в современных медиатекстах, активизирует познавательно-мыслительную деятельность как авторажурналиста, так и читателя-адресата, стимулирует к интеллектуальным поискам обоих коммуникантов в широком и многогранном социокультурном пространстве многих поколений человечества. Психолингвистические механизмы использования интертекстов в масс-медиа связаны с актуализацией определенных образов в сознании журналиста и их вербальной презентацией общеизвестными высказываниями, символами, сюжетами.

Ключевые слова: медиатекст, интертекстуальность, цитата, аллюзия, реминисценция. 